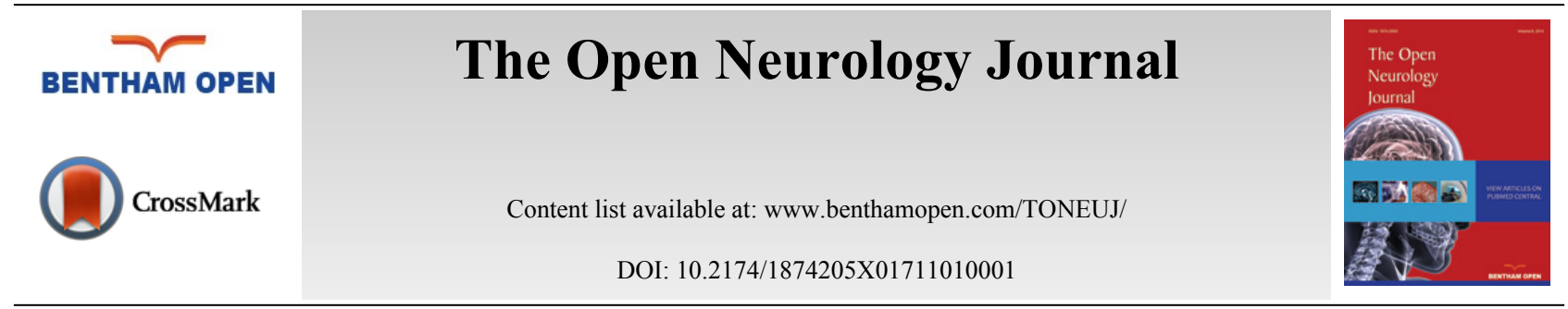

CASE REPORT

\title{
Affection of the Respiratory Muscles in Combined Complex I and IV Deficiency
}

\author{
Josef Finsterer $^{1, *}$, Helmut Rauschka ${ }^{2}$, Liane Segal $^{3}$, Gabor G. Kovacs ${ }^{4}$ and Boris Rolinski ${ }^{5}$ \\ ${ }^{I}$ Krankenanstalt Rudolfstiftung, Vienna, Austria \\ ${ }^{2}$ Neurological Department, SMZO-Donauspital, Vienna, Austria \\ ${ }^{3}$ Department of Anesthesiology, Krankenanstalt Rudolfstiftung, Vienna, Austria \\ ${ }^{4}$ Institute of Clinical Neurology, AKH Wien, Vienna, Austria \\ ${ }_{5}^{5}$ Institute of Clinical Chemistry, Academic Hospital München-Schwabing, Germany
}

Received: August 29, 2016

Revised: December 08, 2016

Accepted: December 13, 2016

\begin{abstract}
:
Objectives:

Combined complex I+IV deficiency has rarely been reported to manifest with the involvement of the respiratory muscles.

\section{Case Report:}

A $45 \mathrm{y}$ male was admitted for hypercapnia due to muscular respiratory insufficiency. He required intubation and mechanical ventilation. He had a previous history of ophthalmoparesis since age $6 y$, ptosis since age $23 \mathrm{y}$, and anterocollis since at least age $40 \mathrm{y}$. Muscle biopsy from the right deltoid muscle at age 41y was indicative of mitochondrial myopathy. Biochemical investigations revealed a combined complex I+IV defect. Respiratory insufficiency was attributed to mitochondrial myopathy affecting not only the extra-ocular and the axial muscles but also the shoulder girdle and respiratory muscles. In addition to myopathy, he had mitochondrial neuropathy, abnormal EEG, and elevated CSF-protein. Possibly, this is why a single cycle of immunoglobulins was somehow beneficial. For muscular respiratory insufficiency he required tracheostomy and was scheduled for long-term intermittent positive pressure ventilation.
\end{abstract}

\section{Conclusion:}

Mitochondrial myopathy due to a combined complex I+IV defect with predominant affection of the extra-ocular muscles may progress to involvement of the limb-girdle, axial and respiratory muscles resulting in muscular respiratory insufficiency. In patients with mitochondrial myopathy, neuropathy and elevated cerebrospinal fluid protein, immunoglobulins may be beneficial even for respiratory functions.

Keywords: Mitochondrial, myopathy, metabolic, neuropathy, CSF-protein, immunoglobulins, progressive external ophthalmoplegia.

\section{INTRODUCTION}

Affection of the respiratory muscles in or excluding the diaphragm has been occasionally reported as the cause of respiratory insufficiency in patients with mitochondrial myopathy (Table 1) [1, 2]. Particularly, patients with progressive external ophthalmoplegia (PEO) seem to be prone to respiratory insufficiency [3]. Mitochondrial myopathy with affection of the respiratory muscles may not only be due to mtDNA but also due to nDNA mutations (Table 1) [1, 2]. Respiratory insufficiency due to affection of the respiratory muscles has to be clearly delineated from respiratory

\footnotetext{
* Address correspondence to this author at the Postfach 20, 1180 Vienna, Austria; Tel: +43-1-71165-92085; Fax: +43-1-4781711; E-mail: fifigs1@yahoo.de
} 
insufficiency due to cerebral involvement in a mitochondrial disorder, like in Leigh- or Leigh-like syndrome or other mitochondrial encephalopathies [4]. Here we report a patient with long-standing PEO and ptosis, and a combined complex I+IV defect who developed successive, late-onset affection of the respiratory muscles.

Table 1. Mitochondrial myopathy due to mutations in mtDNA or nDNA located genes associated with affection of the respiratory muscles.

\begin{tabular}{|c|c|c|c|c|}
\hline References & Gene & Mutation & Biochemical defect & PEO \\
\hline Mar O'Callaghan 2012 [1] & tRNA(Val) & m. $1643 \mathrm{~A}>\mathrm{G}$ & $\mathrm{CII}+\mathrm{CIII}$ & no \\
\hline Behin 2012 [2] & TK2 & c. $323 \mathrm{C}>\mathrm{T}$ & $\mathrm{CI}+\mathrm{CIII}+\mathrm{CIV}$ & no \\
\hline Behin 2012 [2] & TK2 & c. 8 dup, c. $268 \mathrm{C}>\mathrm{T}$ & $\mathrm{CI}+\mathrm{CIII}+\mathrm{CIV}$ & no \\
\hline Wolf 2012 [6] & tRNA(Lys) & $\mathrm{m} .8299 \mathrm{G}>\mathrm{A}$ & $\mathrm{CI}+\mathrm{CIV}$ & yes \\
\hline Smits $2011[3]^{\star}$ & $\mathrm{nm}$ & mtDNA deletion & $\mathrm{nm}$ & yes \\
\hline Martin-Negrier $2011[8]$ & TWINKLE & p.R374Q & $\mathrm{nm}$ & yes \\
\hline Pronicki $2010[20]^{*}$ & $\mathrm{SCO} 2$ & p.E140K & $\mathrm{CIV}$ & no \\
\hline Giordano 2009 [21] & POLG1 & $\mathrm{nm}$ & $\mathrm{nm}$ & no \\
\hline Yuri 2008 [19] & $\mathrm{nm}$ & $\mathrm{nm}$ & $\mathrm{nm}$ & yes \\
\hline Sanaker 2007 [9] & $\mathrm{nm}$ & mtDNAdel & $\mathrm{nm}$ & yes \\
\hline Aure $2007[18]^{\%}$ & $\mathrm{~nm}$ & mtDNAdel & $\mathrm{nm}$ & yes \\
\hline Tong 2006 [22] & $\mathrm{nm}$ & $\mathrm{nm}$ & VLCAD & no \\
\hline Saneto 2006 [23] & tRNA(Leu) & m. $3243 \mathrm{~A}>\mathrm{G}$ & CII overactivity & no \\
\hline Easley $2002[24]$ & $\mathrm{nm}$ & $\mathrm{nm}$ & PDG & no \\
\hline Götz 2002 [10] & $\mathrm{nm}$ & $\mathrm{nm}$ & $\mathrm{nm}$ & yes \\
\hline Chotmongkol 2001 [11] & $\mathrm{nm}$ & $\mathrm{nm}$ & $\mathrm{nm}$ & yes \\
\hline Klopstock 1999 [12] & tRNA(Leu) & 3243 & $\mathrm{~nm}$ & yes \\
\hline Rabano 1998 [7] & $\mathrm{nm}$ & multiple mtDNAdel & partial CI+CIV & no \\
\hline Von Döbeln 1993 [5] & $\mathrm{nm}$ & $\mathrm{nm}$ & $\mathrm{CI}+\mathrm{CIV}$ & no \\
\hline Enter $1991[25]$ & tRNA(Leu) & m. $3243 \mathrm{~A}>\mathrm{G}$ & nm & no \\
\hline Osanai 1991 [13] & mtDNAdel & $\mathrm{nm}$ & $\mathrm{nm}$ & yes \\
\hline Barohn $1990[14]^{*}$ & $\mathrm{~nm}$ & $\mathrm{~nm}$ & $\mathrm{~nm}$ & yes \\
\hline Nozaki 1990 [15] & $\mathrm{nm}$ & $\mathrm{nm}$ & $\mathrm{CIV}$ & yes \\
\hline Desnuelle 1988 [16] & $\mathrm{nm}$ & $\mathrm{nm}$ & $\mathrm{nm}$ & yes \\
\hline Carroll 1976 [17] & $\mathrm{nm}$ & $\mathrm{nm}$ & $\mathrm{nm}$ & yes \\
\hline
\end{tabular}

Nm: not mentioned. VLCAC: very-long chain acyl-CoA dehydrogenase deficiency, PDG: pyruvate-dehydrogenase, *: 13 homozygous cases, \#: 3 cases, \&: 8 cases with PEO due to mtDNA deletion, $\%: 2$ patients.

\section{CASE REPORT}

The patient is a $45 \mathrm{y}$ Caucasian male, height $182 \mathrm{~cm}$, weight $80 \mathrm{~kg}$, with a previous history of divergence of the ocular bulbs with double vision since age $6 y$, bilateral ptosis since age $23 y$, which was surgically corrected at age $30 y$, ophthalmoparesis since at least age $27 \mathrm{y}$, a syncope at age $30 \mathrm{y}$, and anterocollis since at least age $40 \mathrm{y}$. At age $27 \mathrm{y}$ he had undergone muscle biopsy from the left deltoid muscle showing mild myopathic lesions with increased accumulation of intrafusal glycogen and lipid droplets. Electroneurography at age 27y revealed axonal polyneuropathy. 24h-ECG at age $30 \mathrm{y}$ disclosed an intermittent AV-block II and electroencephalography generalized poly-spike waves in the absence of seizures. Clinical neurologic investigation at age 40y revealed, in addition to the above mentioned abnormalities, bilateral proximal weakness of the upper limbs, a winging scapula bilaterally, and reduced tendon reflexes. Cerebrospinal fluid (CSF) investigations at age 40y revealed elevated protein (1008mg/l, n: 150-450mg/l) exclusively. Needle-(electromyography) EMG of the right anterior tibial muscle at age $40 \mathrm{y}$ showed neurogenic alterations. A Guillain-Barre-syndrome (GBS) was suspected and immunoglobulins administered with a beneficial effect. Transthoracic echocardiography at age 40y revealed mild myocardial thickening. At late age 40y mild weakness of the lower limbs (M5-/M4+) and an abnormal respiratory pattern were noted for the first time. Radioscopy of the lungs did not reveal abnormal mobility of the diaphragm. Lactate stress testing under $40 \mathrm{~W}$ resulted in a lactate increase to $9.5 \mathrm{mmol} / 1$ after 8 minutes. Upon supra-maximal stimulation of the phrenic nerve at age $41 \mathrm{y}$ no answer could be evoked and needle-EMG of the rectus abdominis muscle revealed abnormal spontaneous activity. Muscle biopsy from the right 
deltoid muscle at age 41y showed myopathic features, ragged-red fibers, regenerating fibers, increased number of lipid droplets, glycogen depositions, and some COX-negative fibers. Biochemical investigations of the muscle homogenate revealed a combined complex I+IV defect. The activity of the NADH-CoQ-oxidoreductase was $7.4 \mathrm{U} / \mathrm{g} \mathrm{NCP}$ (n, 15.8-42.84 U/g NCP) and the activity of the cytochrome-c-oxidase $89 \mathrm{U} / \mathrm{g} \mathrm{NCP}(\mathrm{n}, 112-351 \mathrm{U} / \mathrm{g} \mathrm{NCP})$. Investigation for mtDNA deletions or insertions by long-range PCR was normal. Southern blot could not be carried out because of insufficient material. nDNA located genes responsible for mitochondrial myopathy were not tested. The family history was positive for diabetes (grandmother from the mother's side) and cardiac abnormalities (mother).

At age $45 y$ he was admitted for acute respiratory dysfunction in the absence of recent pulmonary infection or embolism with hypercapnia but normal oxygenation due to weakness of the respiratory muscles (Table 2). There was no indication for heart failure. Though he was awake with normal oxygenation, he required intubation and mechanical ventilation because of hypercapnia due to muscular respiratory insufficiency. Clinical neurologic examination revealed ptosis, ophthalmoparesis, weak head anteflexion and retroflexion (M5-), weakness of the upper limbs with distal predominance (M4 to M5-), proximal weakness of the lower limbs (M5-) absent tendon reflexes, generalized wasting, and stocking-type sensory disturbances. Blood tests revealed hyponatriemia $(129 \mathrm{mmol} / 1, \mathrm{n}: 135-150 \mathrm{mmol} / \mathrm{l})$ and slight anemia (Table 1). The diaphragm was moving normally. Cerebral CT was normal. Under controlled ventilation elevated $\mathrm{CO}_{2}$ decreased to near normal values within 3 days (Table 2). On hospital day (hd) 3 he was extubated but respiratory insufficiency with hypercapnia recurred, why he required re-intubation and ventilatory support on hd5 (Table 2). One day after re-intubation, tracheostomy was carried out. Blood gases normalized (Table 2) and from hd8 ventilatory support could be discontinued during daytime. Since a GBS was additionally suspected upon the history and the elevated CSF-protein, immunoglobulins were given. Under this regimen respiratory function further improved and he was able to sit with support during daytime. Unsupported sitting was impossible due to affected truncal muscles.

Table 2. Blood gas analysis during hospitalisation.

\begin{tabular}{|l|l|l|l|l|l|l|l|l|l|l|}
\hline Parameter & RL & hd2 & hd3 & hd4 & hd5 & hd6 & hd7 & hd8 & hd9 & hd10 \\
\hline $\mathrm{pH}$ & $7.38-7.42$ & 7.32 & 7.43 & 7.34 & 7.35 & 7.29 & 7.27 & 7.44 & 7.45 & 7.47 \\
\hline $\mathrm{pCO}_{2}$ & - & 74 & 50 & 54 & 62 & 77 & 70 & 53 & 52 & 44 \\
\hline $\mathrm{BE}$ & - & 10.8 & 8.1 & 3.4 & 7.4 & 9.3 & 4.3 & 10.3 & 10.8 & 7.9 \\
\hline $\mathrm{sO}_{2}$ & - & 99 & 99 & 100 & 95 & 99 & 90 & 100 & 99 & 100 \\
\hline Sodium & $135-150 \mathrm{mmol} / 1$ & 142 & 142 & 141 & nd & nd & 142 & 145 & 142 & nd \\
\hline Lactate & - & 0.7 & 0.6 & 0.6 & 0.5 & nd & 1.1 & 0.7 & 0.8 & nd \\
\hline Erythrocytes & $4.2-5.5 \mathrm{~T} / 1$ & 4.5 & 4.03 & 3.74 & nd & nd & 4.45 & 4.68 & 3.85 & nd \\
\hline
\end{tabular}

RL: reference limits, hd: hospital day, BE: base excess, nd: not done.

\section{DISCUSSION}

The patient was suffering from multisystem abnormalities affecting the extra-ocular muscles (PEO), the axial, limb, and respiratory muscles, the nerves, the heart, and subclinically the cerebrum. Initially, he was diagnosed with GBS and for this reason; he repeatedly received immunoglobulins with some benefits.

The cause of respiratory insufficiency in the presented patient is most likely attributable to progressive weakness of the respiratory muscles from the underlying mitochondrial myopathy. There was no indication for a triggering factor, no involvement of the brainstem, systolic dysfunction, or for lung disease. Typical morphological alterations indicative of a Leigh- or Leigh-like syndrome were absent on cerebral CT.

Combined complex I+IV deficiency has been rarely reported to manifest with involvement of the respiratory muscles [2, 5 - 7]. In the patient reported by Wolf et al. complex I+IV deficiency was due to the tRNA(Lys) mutation m. 8299G $>$ A [6]. In this patient, PEO was associated with recurrent respiratory insufficiency [6]. Another female child with a mitochondrial myopathy developed limb muscle weakness since age $3 \mathrm{y}$. Muscle weakness deteriorated since age $28 \mathrm{y}$. by the age $30 \mathrm{y}$ she developed muscular restrictive respiratory insufficiency [2]. At age 44y, the patient required artificial ventilation throughout night and four hours during daytime [2]. The same author reported another child with mitochondrial myopathy who developed progressive muscle weakness and wasting and respiratory insufficiency since age 31y [2]. Both patients carried a combined complex I+III+IV defect. Genetic tests revealed the mutation c.323C $>\mathrm{T}$ in the TK2 gene in patient 1 and the c.8dup duplication in the TK2 gene in patient 2 [2]. Partial complex I+IV defect was detected in the muscle of a 13y patient who developed sudden-onset of respiratory insufficiency and quadruspasticity, which was attributed to leukodystrophy [7]. 
Previously, several patients with PEO and affection of the respiratory muscles have been described (Table 1) $[3,6,8$ - 19]. In a study of 23 patients with PEO, eight had reduced maximal expiratory mouth pressure $<65 \%$ [3]. In all eight patients, PEO was due to single mtDNA deletions [3]. In a patient with Kearns-Sayre syndrome (KSS), acute respiratory failure developed requiring invasive ventilatory support, which improved to a level where she required only non-invasive nocturnal BiPAP treatment [9]. In another patient with KSS, respiratory insufficiency with alveolar hypoventilation was attributed to diminished chemosensitivity to hypoxia and hypercapnia [13]. Reduced ventilatory drive due to depressed response to hypoxia or hypercapnia was also reported in three other patients with PEO [14]. In a study on the cause of death in 16 patients with PEO it turned out that two of them died from cardiopulmonary insufficiency without further specification of the respiratory contribution [12]. Two studies have shown that respiratory insufficiency can be the main cause of death in patients with PEO [12, 18]. In a study of 69 patients with PEO, two developed muscular respiratory failure and died from it [18]. In this study, the probability to develop extra-ocular manifestations was increased if onset of PEO was before the age 9y and was correlated with the amount of mtDNA deletion in blood lymphocytes [18]. Other patients with mitochondrial myopathy but without PEO or a combined complex I+IV defect who developed respiratory insufficiency from mitochondrial myopathy are listed in Table $\mathbf{1}$ [1, 20 - 25]. Patients with mitochondrial myopathy and PEO who developed respiratory insufficiency but unknown genetic or biochemical defect have also been reported [11, 14, 16, 17].

Treatment of respiratory insufficiency has been described elsewhere [3]. A major complication of decreased respiratory muscle weakness in mitochondrial myopathy is an increased risk of pneumonia [26]. If there is additional involvement of the laryngeal muscles, these patients are particularly prone to develop pneumonia since laryngeal muscle weakness may lead to aspiration of food and to insufficient glottis closure during coughing [12, 27, 28]. When insufficient glottis closure is combined with decreased inspiratory or expiratory strength, this may result in decreased generation of intra-thoracic pressure and thus impaired expectoration [3]. The mild beneficial effect of immunoglobulins might be due to a placebo effect, due to secondary immunological disease, or due to a chronic inflammatory demyelinating polyneuropathy (CIDP) as a second trouble. Arguments for a CIDP are the elevated CSFprotein, and the response to immunoglobulins. Arguments against CIDP, however, are that polyneuropathy was of the axonal type, that the immunoglobulin effect was only mild, and that mitochondrial myopathy has not been reported in association with CIDP. Immunoglobulins have not been reported to be generally beneficial in mitochondrial disorders.

\section{CONCLUSION}

This case shows that a mitochondrial disorder due to a combined complex I+IV defect manifesting predominantly with PEO may progress to involvement of the limb-girdle, axial, and respiratory muscles, resulting in muscular respiratory insufficiency. In patients with a mitochondrial myopathy, neuropathy, and elevated CSF-protein, immunoglobulins may exhibit a beneficial effect.

\section{CONFLICT OF INTEREST}

The authors confirm that this article content has no conflict of interest.

\section{ACKNOWLEDGEMENTS}

Declared none.

\section{REFERENCES}

[1] del Mar OCallaghan M, Emperador S, López-Gallardo E, et al. New mitochondrial DNA mutations in tRNA associated with three severe encephalopamyopathic phenotypes: neonatal, infantile, and childhood onset. Neurogenetics 2012; 13(3): 245-50. [http://dx.doi.org/10.1007/s10048-012-0322-0] [PMID: 22638997]

[2] Béhin A, Jardel C, Claeys KG, et al. Adult cases of mitochondrial DNA depletion due to TK2 defect: an expanding spectrum. Neurology 2012; 78(9): 644-8.

[http://dx.doi.org/10.1212/WNL.0b013e318248df2b] [PMID: 22345218]

[3] Smits BW, Heijdra YF, Cuppen FW, van Engelen BG. Nature and frequency of respiratory involvement in chronic progressive external ophthalmoplegia. J Neurol 2011; 258(11): 2020-5. [http://dx.doi.org/10.1007/s00415-011-6060-7] [PMID: 21533826]

[4] Miyabayashi S, Narisawa K, Iinuma K, et al. Cytochrome C oxidase deficiency in two siblings with Leigh encephalomyelopathy. Brain Dev 1984; 6(4): 362-72.

[http://dx.doi.org/10.1016/S0387-7604(84)80112-6] [PMID: 6093613] 
[5] von Döbeln U, Wibom R, Ahlman H, et al. Fatal neonatal lactic acidosis with respiratory insufficiency due to complex I and IV deficiency. Acta Paediatr 1993; 82(12): 1079-81. [http://dx.doi.org/10.1111/j.1651-2227.1993.tb12818.x] [PMID: 8155932]

[6] Wolf J, Obermaier-Kusser B, Jacobs M, et al. A new mitochondrial point mutation in the transfer RNA(Lys) gene associated with progressive external ophthalmoplegia with impaired respiratory regulation. J Neurol Sci 2012; 316(1-2): 108-11. [http://dx.doi.org/10.1016/j.jns.2012.01.013] [PMID: 22326363]

[7] Rábano JA, Playan A, Guirado F, Montoya J, Baldellou A, López-Pisón J. Acute presentation of leukodystrophy due to mitochondrial cytopathology and multiple deletions of mitochondrial DNA. Rev Neurol 1998; 27(160): 1005-7. [PMID: 9951025]

[8] Martin-Negrier ML, Sole G, Jardel C, Vital C, Ferrer X, Vital A. TWINKLE gene mutation: report of a French family with an autosomal dominant progressive external ophthalmoplegia and literature review. Eur J Neurol 2011; 18(3): 436-41. [http://dx.doi.org/10.1111/j.1468-1331.2010.03171.x] [PMID: 20880070]

[9] Sanaker PS, Husebye ES, Fondenes O, Bindoff LA. Clinical evolution of Kearns-Sayre syndrome with polyendocrinopathy and respiratory failure. Acta Neurol Scand Suppl 2007; 187: 64-7. [http://dx.doi.org/10.1111/j.1600-0404.2007.00850.x] [PMID: 17419832]

[10] Götz J, Carlsson J, Schipmann R, et al. 37-year-old patient with eye muscle paralysis and rapidly progressing respiratory insufficiency. Internist (Berl) 2002; 43(4): 548-53.

[PMID: 12053411]

[11] Chotmongkol V, Intarapoka B, Mitchai J. Mitochondrial myopathy with respiratory dysfunction: a case report. J Med Assoc Thai 2001; 84(3): 445-7. [PMID: 11460950]

[12] Klopstock T, Jaksch M, Gasser T. Age and cause of death in mitochondrial diseases. Neurology 1999; 53(4): 855-7. [http://dx.doi.org/10.1212/WNL.53.4.855] [PMID: 10489054]

[13] Osanai S, Ohmiya H, Akashi K, et al. A case of Kearns-Sayre syndrome with impaired respiratory regulation. Nihon Kyobu Shikkan Gakkai Zasshi 1991; 29(10): 1334-8. [PMID: 1753513]

[14] Barohn RJ, Clanton T, Sahenk Z, Mendell JR. Recurrent respiratory insufficiency and depressed ventilatory drive complicating mitochondrial myopathies. Neurology 1990; 40(1): 103-6.

[http://dx.doi.org/10.1212/WNL.40.1.103] [PMID: 2296355]

[15] Nozaki H, Hamano S, Ueoka Y, Horita H, Koga Y, Nonaka I. Cytochrome c oxidase deficiency with acute onset and rapid recovery. Pediatr Neurol 1990; 6(5): 330-2. [http://dx.doi.org/10.1016/0887-8994(90)90026-W] [PMID: 2173614]

[16] Desnuelle C, Pellissier J-C, Serratrice G, Pouget J. Chronic progressive external ophthalmoplegia (CPEO) associated with diaphragm paralysis: successful treatment with Coenzyme Q (CoQ). Neurology 1988; 38: 102-3.

[17] Carroll JE, Zwillich C, Weil JV, Brooke MH. Depressed ventilatory response in oculocraniosomatic neuromuscular disease. Neurology 1976; 26(2): 140-6. [http://dx.doi.org/10.1212/WNL.26.2.140] [PMID: 943069]

[18] Auré K, Ogier de Baulny H, Laforêt P, Jardel C, Eymard B, Lombès A. Chronic progressive ophthalmoplegia with large-scale mtDNA rearrangement: can we predict progression? Brain 2007; 130(Pt 6): 1516-24.

[http://dx.doi.org/10.1093/brain/awm067] [PMID: 17439982]

[19] Yuri T, Kondo Y, Kohno K, et al. An autopsy case of chronic progressive external ophthalmoplegia with renal insufficiency. Med Mol Morphol 2008; 41(4): 233-7. [http://dx.doi.org/10.1007/s00795-008-0420-0] [PMID: 19107614]

[20] Pronicki M, Kowalski P, Piekutowska-Abramczuk D, et al. A homozygous mutation in the $\mathrm{SCO}_{2}$ gene causes a spinal muscular atrophy like presentation with stridor and respiratory insufficiency. Eur J Paediatr Neurol 2010; 14(3): 253-60. [http://dx.doi.org/10.1016/j.ejpn.2009.09.008] [PMID: 19879173]

[21] Giordano C, Powell H, Leopizzi M, et al. Fatal congenital myopathy and gastrointestinal pseudo-obstruction due to POLG1 mutations. Neurology 2009; 72(12): 1103-5.

[http://dx.doi.org/10.1212/01.wnl.0000345002.47396.e1] [PMID: 19307547]

[22] Tong MK, Lam CS, Mak TW, et al. Very long-chain acyl-CoA dehydrogenase deficiency presenting as acute hypercapnic respiratory failure. Eur Respir J 2006; 28(2): 447-50. [http://dx.doi.org/10.1183/09031936.06.00139205] [PMID: 16880373]

[23] Saneto RP, Bouldin A. A boy with muscle weakness, hypercarbia, and the mitochondrial DNA A3243G mutation. J Child Neurol 2006; 21(1): 77-9.

[http://dx.doi.org/10.1177/08830738060210010601] [PMID: 16551459]

[24] Easley RB, Johnson TR, Tobias JD. Continuous pH monitoring using the Paratrend 7 inserted into a peripheral vein in a patient with shock and congenital lactic acidosis. Clin Pediatr (Phila) 2002; 41(5): 351-5. 
[http://dx.doi.org/10.1177/000992280204100508] [PMID: 12086201]

[25] Enter C, Müller-Höcker J, Zierz S, et al. A specific point mutation in the mitochondrial genome of Caucasians with MELAS. Hum Genet 1991; 88(2): 233-6.

[http://dx.doi.org/10.1007/BF00206080] [PMID: 1684568]

[26] Braun NM, Arora NS, Rochester DF. Respiratory muscle and pulmonary function in polymyositis and other proximal myopathies. Thorax 1983; 38(8): 616-23.

[http://dx.doi.org/10.1136/thx.38.8.616] [PMID: 6412385]

[27] Kornblum C, Broicher R, Walther E, et al. Cricopharyngeal achalasia is a common cause of dysphagia in patients with mtDNA deletions. Neurology 2001; 56(10): 1409-12. [http://dx.doi.org/10.1212/WNL.56.10.1409] [PMID: 11376201]

[28] Smith PE, Calverley PM, Edwards RH, Evans GA, Campbell EJ. Practical problems in the respiratory care of patients with muscular dystrophy. N Engl J Med 1987; 316(19): 1197-205.

[http://dx.doi.org/10.1056/NEJM198705073161906] [PMID: 3553943]

(C) Finsterer et al.; Licensee Bentham Open

This is an open access article licensed under the terms of the Creative Commons Attribution-Non-Commercial 4.0 International Public License (CC BY-NC 4.0) (https://creativecommons.org/licenses/by-nc/4.0/legalcode), which permits unrestricted, non-commercial use, distribution and reproduction in any medium, provided the work is properly cited. 